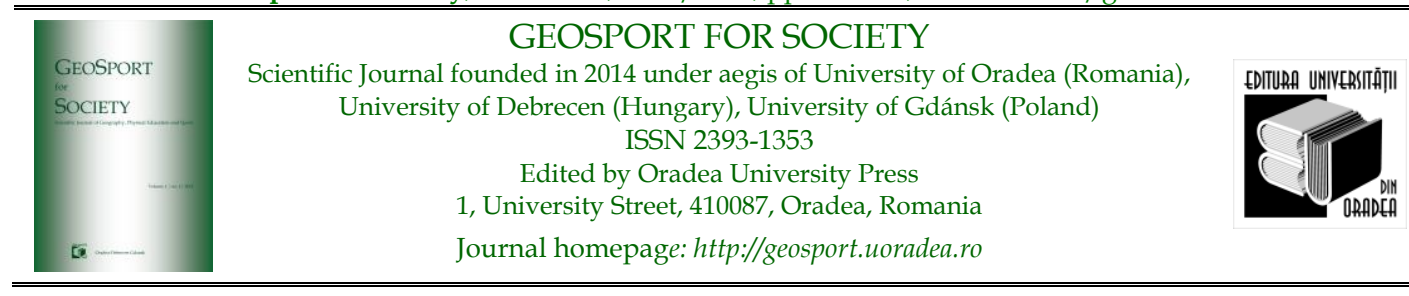

\title{
Dual career (profession and sport) in academic system - a premise for the existence a regular university football championship in Romania
}

\author{
Alexandru ILIEȘ1*, Sorin Dacian BUHAȘ1 \\ 1. University of Oradea, 1 University st., 410087 Oradea, Bihor, Romania, e-mails: $\underline{\text { ilies@uoradea.ro, }}$ \\ sorin.buhas@gmail.com \\ * Corresponding author
}

Citation: Ilieș, A., \& Buhaș, S.D. (2020). Dual academic system education and sport - a premise for the existence a regular university football championship in Romania. Geosport for Society, 13(2), 149-164. https://doi.org/10.30892/gss.1306-066

Article history: 10.11.2020; Revised: 15.12.2020; Accepted: 22.12.2020, Available online: 29.12.2020

\begin{abstract}
University football has tradition in the Romanian political context. The first teams that made history in amateur and later professional football were founded in the early twentieth century by students who returned to the country after completing their studies abroad. Through this study, based on the experience in already traditional championships such as the British one, we propose a strategy for implementing such a dual system based on professional development and sports in the Romanian academic environment. The existence of 93 public and private universities (in 2020) ${ }^{2}$ with own specific infrastructure, 22 university centers and about 0.4 million students provide a "fertile ground" for such approach, for competitions with male and female teams. Through specific methods in the field of territorial planning and geography this study presents: the competitive design, the implementation strategy, human resources, infrastructure, spatial models with systemic functionality, etc. Sport in general and football in particular have proven to be the most effective ambassadors of a community, nation or institution etc.
\end{abstract}

Keywords: universities, students, university football, university championship, national university league, university football in Romania

\section{Introduction}

The idea of a functional systemic construction of a national university football championship in Romania has been germinating in the university environment for a long time as evidenced by the tournaments organized sporadically in the last 40 years. Either at university centers or at national level, inter-university football competitions existed both during the socialist period and after (Buhaș et al., 2017), especially in the last decade. If before 1990 a national competition with 
international participation entitled "Universiade" was organized, in the last decade, thanks to the Federation of School and University Sports and with the support of the Romanian Football Federation, 5 editions of the national university football tournament were organized ${ }^{1}$. It is to be noted the contribution of 27 participating universities from 16 universities center and especially the role assumed by the organizer of the Polytechnic University of Timisoara (editions: 2015, 2017 and 2019) and Babes-Bolyai University of Cluj-Napoca (editions 2016 and 2018). Currently, there are 93 public and private universities in Romania that can provide the necessary human resources and, most importantly, most of them have their own specific infrastructure (Dragoș, 2015).

In this study we present the favorable premises for such an approach, the operating framework, the human resources and infrastructure and a functional competitive system model. All the aspects presented are supported by an adequate and suggestive graphic and cartographic representation.

The basic idea is to make the university environment even more attractive by promoting dual career (Aquilina and Henry, 2010; Guidotti et al., 2015; Ilieș and Caciora, 2020) "the dual form of university life based on continuing to practice a sport in an organized way, in parallel with university professional training" (Oros and Hanțiu, 2018). Inspired by the British model with long experience ${ }^{3}$, such a functional territorial system can be successfully implemented in the Romanian university environment as well based on a well-founded scientific and economic strategy. Moreover, the organization involves both men's and women's competitions.

\section{Methodology}

The establishment of a functional database, with up-to-date information from credible primary sources (universities in the first place), represents the first stage of this approach. The next step is to manage this database through GIS, a modern tool for managing statistical data (Robinson et al., 2017) and images, especially suggestively through complex cartographic materials expressively realized. One of the advantages of this tool is that it is constantly updated, which is also reflected in the diversified range of cartographic products created (Ilieș et al., 2015a; O'Brien and Cheshire, 2015; Ilieș et al., 2016a; Murphy, 2019; Ilieș and Caciora, 2020). The advantage of this tool also derives from the fact that it is constantly updated, which is also reflected in the diversified range of cartographic products made. The methods of representation and spatial analysis (Cartwright and Sørensen, 2009; Ilieș et al., 2016a; Dehoorne et al., 2019), specific to the geography of sport (Bale, 2003; Conner, 2014; Ilieș et al., 2014; Chirazi, 2019) and territorial planning, facilitate quantitative and qualitative spatial analyzes (Caput-Jogunica et al., 2012; Candello et al., 2019; Bulz and Ilieș, 2017; Gartner and Huang, 2016), the use of indicators, the creation of typologies etc. An important role is played by the spatial transposition that facilitates a better understanding of the systemic functioning mechanisms of a sports competition (Buhaș, 2015) and of the systemic "puzzle" formed by the dynamic component: human resource and the static resource: the infrastructure (Augustin, 2007; Ilieș et al., 2015b; 2016b; Graczyk et al., 2017; Olszewski-Strzyżowski, 2018). 


\section{The analytical framework}

In Romania, with a population of about 21 million inhabitants, there are 22 university centers that host the headquarters of 93 public and private universities. In the academic year 2019/2020 there were about 0.4 million students distributed in 55 state universities ( 0.35 million students) and 38 private universities (about 55,000 students). To the university centers that house the main headquarters of the universities are added another 28 university centers, in urban localities of different sizes which host branches of the mentioned universities ${ }^{2}$.

The data presented are favorable indicators in order to establish a regular university sports movement on the football branch that can be extended to other sports as well (Herman et al., 2018; Lucaciu, 2018). The "fertile land" of the Romanian university environment also results from the comparison with the Scottish part of the British integrated system: Scotland with 5.454 million inhabitants, with 19 universities, about 231,000 students. In the 2019/2020 season, 15 universities participated in parallel in 5 university competitions (one championship and 4 cups) with 75 university football teams ( +7 colleges) organized on 7 levels ( 7 leagues) but also in Scottish amateur football competitions (leagues 3 and 4). Around 1855 students practice football in an organized way and on a regularly basis, being legitimized at 19 clubs with women's teams (525 players) and 53 with men's teams (1330 players). The universities of Edinburgh and St Andrews are enrolled in men's and women's university competitions with 9 teams each (Ilieș and Caciora, 2020). We mention that the Scottish teams are part of a 9-tier UK university championship system, which includes over 1,000 men's and women's teams ${ }^{3}$.

In these conditions, this study tries to provide a practical answer to the question why football should neglect this educated segment (Böheim and Lackner, 2012) and which can more easily understand and promote the importance of sport for health and life?, especially since the athlete is the best international ambassador and sport is the mirror of a nation, community (Rotar and Ursu, 2019; Kijewski and Wendt, 2019).

\section{"Reinventing" the national university championship}

After the fall of the socialist system several sporadic attempts to resurrect university football competitions were undertaken. Unfortunately, only recently has been ensured the continuity through the last 5 editions of the National University Football Championship of Romania, men, consecutively held under the auspices of the Federation of School and University Sports in partnership with the Romanian Football Federation. Unfortunately, the sixth edition, with a final tournament scheduled in Oradea, did not take place due to the COVID-19 pandemic. The last 5 editions of the National University Football Championship of Romania, where the interest was shown by the number of participating institutions, by the way of organization, by the human resources involved, by the way of institutional involvement in organization and participation, by the way in which the competition and the participating universities were promoted at sports level, through the image created for the Romanian university sport following the participation of the Romanian champion in the European competition etc, are arguments that encourage us to theoretically and practically complete such an approach. 
The "directors" on which the restart of the university championship in the third millennium was based on had optimistic and substantial messages, and the evidence is their support and involvement in all 5 successive editions developed so far. Only the COVID19 pandemic caused the sixth edition scheduled in Oradea to be postponed. Only the COVID-19 pandemic situation postponed the sixth edition planned to be held in Oradea. The Director of the Competition, the journalist Stăncioiu Octavian, optimistic since the first edition of this project, claimed that Elitist by definition, the university environment may contribute decisively to the revitalization of Romanian football ${ }^{1}$ (Stăncioiu, 2015). Through the director's message, FSSU, the main partner, stands for the importance of the university football and sustains that This project confirms us, through the reciprocity system promoted and agreed by the participating universities, that sport remains an essential element in university life, meant to increase the bio-psycho-motor potential of students, to develop their associative life and respect for rules in order to increase the degree of socialization... We also aimed to increase the internationally prestige of Romanian universities also through sports. The winning university will represent our country at the European University Football Championship. ${ }^{1}$ (Georgescu, 2015). Ciprian Paraschiv reinforces the above-mentioned words and states that For the first time, the Romanian Football Federation is involved in organizing a National University Football Championship in 11 players and I am convinced that this event is only the first page of a beautiful collaboration ${ }^{1}$ (Paraschiv, 2015). As the host of the first tournament in 2015, the Rector of the Polytechnic University of Timișoara, prof. Viorel Șerban, one of those who contributed to the post-December student football renaissance ${ }^{1}$ of the Polytechnic of Timișoara predicted the continuity of university sports, claiming that I am confident that this project - and those that will follow in this format - will give a signal to public opinion, perhaps a modest one for now, on what can and should a University be in society nowadays. The voice of universities must be heard, society must receive a signal thing can be done differently, that the natural and healthy state is that of normalcy, of cultivating human solidarity, and of hope for the better ${ }^{1}$ (SSerban, 2015).

Through this study we want to offer a theoretical support with practical applicability to continue and develop the activity of the representatives of the institutions that organized the previous editions. We refer to the host institutions of the final tournaments (figure 1): Polytechnic University of Timișoara - 2015, 2018 and 2019 editions, Babeș-Bolyai University of Cluj-Napoca, 2016, 2017 editions and to the 27 participating universities from 15 university centers: December 1, 1918 University of Alba Iulia (1D1918.U); from Arad (2): Aurel Vlaicu University (AV.U) and Vasile Goldiș West University (VGW.U); Transilvania University of Brașov (T.U); from Bucharest (5): Alexandru Ioan Cuza Police Academy (AIC.P.A), Ecological University (E.U), National University of Physical Education and Sports (NUPES), Polytechnic University (P.U) and University of Agronomic Sciences and Veterinary Medicine U.ASVM); from Cluj-Napoca (3): Babeș-Bolyai University (BB.U; champion in 2016 and 2018); University of Agronomic Sciences and Veterinary Medicine (U.ASVM) and Technical University (T.U); from Iași: Alexandru Ioan Cuza University (AIC.U), Grigore T. Popa University of Medicine and Pharmacy (GTP.MP.U) and Gheorghe Asachi 
Technical University (GAT.U); University of Oradea (Oradea U.); University of Petroșani (Petroșani U.); University of Pitești (Pitești U.); Lucian Blaga University of Sibiu (LB.U); Valahia University of Târgoviște (V.U); Constantin Brâncuși University of Tg Jiu (CB.U; champion in 2015); Petru Maior University of Târgu Mureș (PM.U); from Timișoara (3): West University (W.U; champion in 2017 and 2019), Polytechnic University (P.U) and Ioan Slavici University (IS.U).

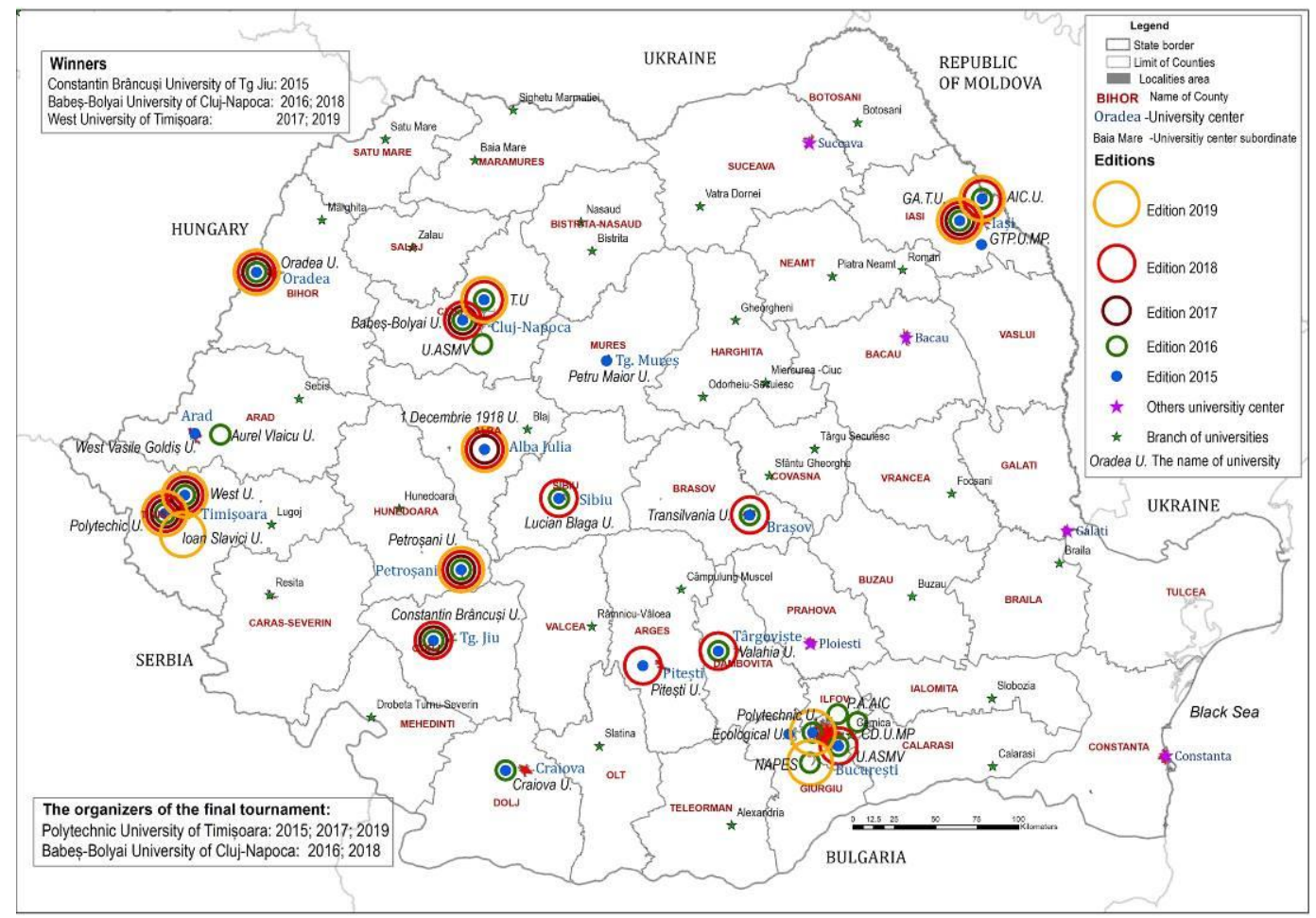

Figure 1. Universities participating in the 5 editions of the National University Football Championship of Romania $4 ; 5$

The champions participating in the European competition achieved the following performances 15 : edition 2015, Osijek (Croatia) 2015, $5^{\text {th }}$ place: Constantin Brâncuși University of Tg Jiu; edition 2016, Zagreb and Rijeka (Croația), ${ }^{\text {th }}$ palce: Babeș-Bolyai University of Cluj-Napoca; edition 2017, Porto (Portugal), 9th place: West University of Timișoara; edition 2018, Coimbra (Portugal), 9 $9^{\text {th }}$ place: BabeșBolyai University of Cluj-Napoca; edition 2019, Madrid (Spain), 9th place: West University of Timișoara.

\section{Tradition and professionalism}

At the level of 2020, in amateur and professional football in Romania (Herman et al., 2016), there are 17 sports clubs with football teams that are established by higher education institutions. 


\section{A.) In 2020 (figure 2; table 1), in professional and amateur football championsips $^{6 ; 7}$, there are 16 university clubs and associations with 22 women's (7) and men's (15) football teams connected with higher education institutions or are in such a partnership (Ilieș et al., 2015b).}

B.)

Table 1. The Associations and clubs with women's and men's football teams connected with higher education institutions in professional and amateur leagues $6 ; 7$

\begin{tabular}{|c|c|c|c|c|c|c|c|c|c|c|}
\hline \multirow[t]{2}{*}{ no } & \multirow[t]{2}{*}{$\begin{array}{l}\text { Club } \\
\text { logo }\end{array}$} & \multirow[t]{2}{*}{ Supporting university and teams } & \multirow[t]{2}{*}{ since } & \multicolumn{3}{|c|}{$\begin{array}{c}\text { National } \\
\text { professional } \\
\text { league }\end{array}$} & \multicolumn{4}{|c|}{$\begin{array}{l}\text { Amateur } \\
\text { regional and } \\
\text { local leagues }\end{array}$} \\
\hline & & & & 1 & 2 & 3 & 4 & 5 & 6 & 7 \\
\hline 1 & & $\begin{array}{l}\text {-CSU Universitatea Craiova } 1948 \text { is supported by the } \\
\text { University and the the Mayor's Office of Craiova; } \\
\text {-The club has two men's teams: in the } 1^{\text {st }} \text { and in the } 2^{\text {nd }} \\
\text { leagues. }\end{array}$ & $\begin{array}{c}(1948) \\
2013\end{array}$ & & & & & & & \\
\hline 2 & & $\begin{array}{l}\text { FC Politehnica Iași is supported by the Gheorghe Asachi } \\
\text { Technical University and the Mayor's Office of Iași; } \\
\text {-The club has one men's team in the } 1^{\text {st }} \text { league. }\end{array}$ & $\begin{array}{c}(1945) \\
2010\end{array}$ & & & & & & & \\
\hline 3 & & $\begin{array}{l}\text { FC Universitatea Galați is supported by the Dunărea de Jos } \\
\text { University of Galați; } \\
\text {-The club has } 2 \text { women's teams in the } 1^{\text {st }} \text { and in the } 3^{\text {rd }} \\
\text { leagues; }\end{array}$ & 2015 & & & & & & & \\
\hline 4 & & $\begin{array}{l}\text {-CS Universitatea Alexandria is supported by the Mayor's } \\
\text { Office of Alexandria; } \\
\text {-The club has one women's team in the } 1^{\text {st }} \text { league }\end{array}$ & 2012 & & & & & & & \\
\hline \multirow[t]{2}{*}{5} & \multirow[t]{2}{*}{ (1) ORSITATS? } & $\begin{array}{l}\text {-FC Universitatea Olimpia Cluj-Napoca is supported by the } \\
\text { Babes-Bolyai University and CS Universitatea Cluj-Napoca; } \\
\text {-The club has } 2 \text { women's teams in the } 1^{\text {st }} \text { and in the } 2^{\text {nd }} \\
\text { leagues; } \\
\text {-The team won the title of Champion of Romanian in } 9 \\
\text { editions (2011-2020) }\end{array}$ & 2010 & & & & & & & \\
\hline & & $\begin{array}{l}\text { FC Universitatea Cluj-Napoca is the result of the association } \\
\text { between } 4 \text { universities and the Mayor's Office of Cluj } \\
\text { Napoca; } \\
\text {-The club has one men's team in the } 2^{\text {nd }} \text { League. }\end{array}$ & 1919 & & & & & & & \\
\hline \multirow[t]{2}{*}{6} & & $\begin{array}{l}\text {-ASU Politehnica Timișoara is supported by the Polytehnic } \\
\text { University of Timisoara; } \\
\text {-The club has two men's teams in the } 2^{\text {nd }} \text { and in the } 7^{\text {th }} \\
\text { leagues. }\end{array}$ & 2012 & & & & & & & \\
\hline & & -The club has one women's team in the $3^{\text {rd }}$ league & 2018 & & & & & & & \\
\hline 7 & & $\begin{array}{l}\text {-The club FC Ripensia UVT Timișoara is in partnership with } \\
\text { the West University of Timișoara; } \\
\text {-The club has one men's team in the } 2^{\text {nd }} \text { league. }\end{array}$ & $\begin{array}{c}(1928) \\
2012\end{array}$ & & & & & & & \\
\hline 8 & $\underset{\substack{\text { STUDENT SPORT } \\
\text { ALBAIULA }}}{\text { TAT }}$ & $\begin{array}{l}\text {-ACS Student Sport Alba Iulia (L2) is supported by the } 1 \\
\text { December } 1918 \text { University and the the Mayor's Office of } \\
\text { Alba Iulia; } \\
\text {-The club has one women's team in the } 2^{\text {nd }} \text { league }\end{array}$ & 2018 & & & & & & & \\
\hline 9 & कiin & $\begin{array}{l}\text { ACS Unirea Politehnica București is supported by the } \\
\text { Polytehnic University of Bucharest; } \\
\text {-The club has one men's team in the } 4^{\text {th }} \text { league Bucharest }\end{array}$ & 2018 & & & & & & & \\
\hline 10 & & $\begin{array}{l}\text { AS FC Universitatea Oradea is supported by the University of } \\
\text { Oradea; } \\
\text {-The club has one men's team in the } 4^{\text {th }} \text { league Bihor County }\end{array}$ & 2011 & & & & & & & \\
\hline 11 & (nem & $\begin{array}{l}\text {-CS Universitatea } 1 \text { Decembrie } 1918 \text { Alba Iulia is supported by } \\
\text { the December } 1,1918 \text { University of Alba Iulia } \\
\text {-The club has one men's team in the } 4^{\text {th }} \text { league Alba County }\end{array}$ & 2018 & & & & & & & \\
\hline
\end{tabular}




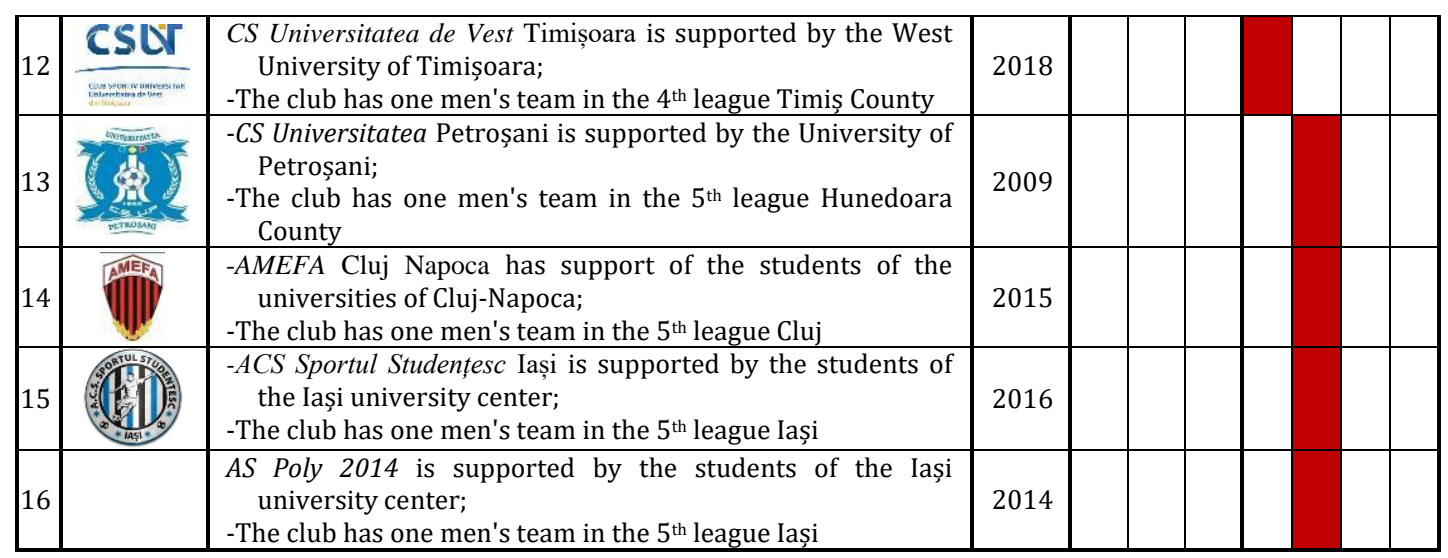

Other football clubs with names inspired by university brands are active in Romanian fooball professional leagues in Timișoara and Craiova (figure 2; table 2) ) $^{6}$

Table 2. The men's football teams inspired by the university brands active in professional leagues in Romania6;7

\begin{tabular}{|c|c|c|c|c|c|c|}
\hline \multirow[t]{2}{*}{ no } & \multirow[t]{2}{*}{ Logo } & \multirow[t]{2}{*}{ Supporting university } & \multirow[t]{2}{*}{ since } & \multicolumn{3}{|c|}{$\begin{array}{c}\text { professional } \\
\text { league }\end{array}$} \\
\hline & & & & 1 & 2 & 3 \\
\hline 1 & & $\begin{array}{l}\text {-ACS Politehnica Timișoara (activated in national league) is supported by the } \\
\text { local authorities in Timiș County. } \\
\text {-The club has one men's team in the } 3^{\text {rd }} \text { league. }\end{array}$ & $\begin{array}{c}(1921) \\
2012\end{array}$ & & & \\
\hline 2 & & $\begin{array}{l}\text {-FC Universitatea } 1948 \text { Craiova, without connection with the higher education } \\
\text { institution, but which claims to be the continuator of the university club. It is } \\
100 \% \text { private club. } \\
\text {-The club has two men's teams in the } 2^{\text {nd }} \text { and in the } 3^{\text {rd }} \text { national leagues. }\end{array}$ & 1948 & & & \\
\hline
\end{tabular}

After the fall of the socialist system (1990), 5 university clubs were temporarily active in Romanian football (figure 2; table 3). In 2017, one year after the centenary (1916-2016), the oldest and one of the most performing student football clubs in Romania, Sportul Studentesc București, disappeared6;7.

Table 3. The men's football teams connected with higher education institutions in professional and amateur leagues were temporarily active after 1990 (exception FC Sportul Studențesc) 6;7

\begin{tabular}{|c|c|c|c|c|c|c|c|}
\hline & & & & & & F.c. vetialap Bacau & \\
\hline $\begin{array}{c}\text { FC Sportul } \\
\text { Studențesc } \\
\text { București } \\
\text { (L1) (1916- } \\
\text { 2017) }\end{array}$ & $\begin{array}{c}\text { ACS } \\
\text { Universitatea } \\
\text { Dunărea de } \\
\text { Jos Galați } \\
\text { (L3) } \\
(2017-2020)\end{array}$ & $\begin{array}{c}C S \\
\text { Universitar } \\
\text { Voința Sibiu } \\
\text { (L1) } \\
(2007-2012)\end{array}$ & $\begin{array}{c}F C \\
\text { Maramureș } \\
\text { Universitar } \\
\text { Baia Mare } \\
\text { (L2) (2010- } \\
\text { 2013) }\end{array}$ & $\begin{array}{c}\text { Atletic Club } \\
\text { Universitar } \\
\text { Arad (L2) } \\
\text { (1995- } \\
\text { 2011) }\end{array}$ & $\begin{array}{c}F C \\
\text { Politehnica } \\
\text { Timișoara } \\
\text { (L1) } \\
(1921- \\
\text { 2012) }\end{array}$ & $\begin{array}{c}\text { FC Știința } \\
\text { Bacău } \\
\text { (L2) } \\
2008-2009\end{array}$ & $\begin{array}{c}\text { CS U-Nord } \\
\text { Baia Mare } \\
\text { (2003-2009; } \\
\text { (L4 } \\
\text { Maramureș) }\end{array}$ \\
\hline
\end{tabular}

The only professional football team (league 3) administratively related to a high school (Cetate National Sports College) was, in the period 2013-2020, CNS Cetate/LPS Cetate Deva. From 2020 became CSM Deva and passed into the administration of the Mayor's Office of Deva ${ }^{8}$. 


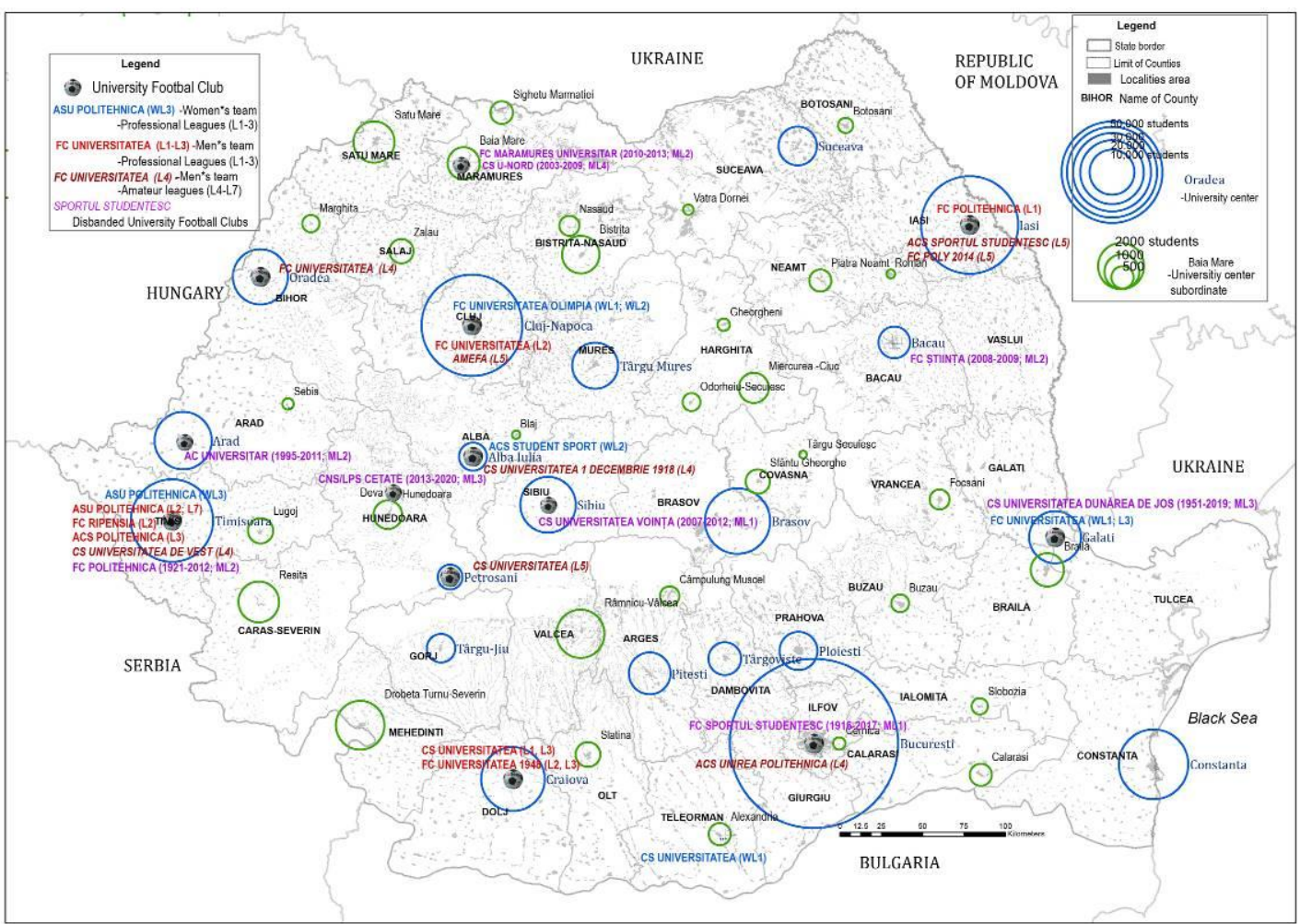

Figure 2. University sports clubs / associations with football teams participating in professional (Leagues 1-3) and amateur (leagues 4-7) competitions in Romania6; 7

\section{Why a national university football league?}

The implementation of dual university models in Great Britain, USA, Portugal, Spain, Germany, Russia, China, South Africa, Canada etc. demonstrates through their success the importance of the connection between sports in general and football in particular and university professional training (Reilly and Gilbourne, 2003; Tight, 2002; Donnor, 2005; Humphreys, 2006; Gayles and Hu. 2009). In Romania, for example, the name "University" in Craiova will remain for a long time with priority related to the football team in the national collective mentality, compared to the higher education institution that was the basis for its establishment in 1948.

The main purpose of establishing a national university football league has the following objectives:

- increasing the institutional visibility at the highest level, sport being the most important ambassador or means of promotion on any level and in any field;

- increasing the degree of social integration of the institution in the daily life of the university but also at regional level (Kozma, 2014; Kozma et al., 2015);

- promoting and implementing the dual concept of professional training and sports (profession and passion) with multiple advantages for young people who were enrolled in performance sports during their junior age (up to 18 years).

-promoting and efficient use of its own infrastructure, in most university campuses there are homologable grounds for football competitions in 11 (fig.3). 


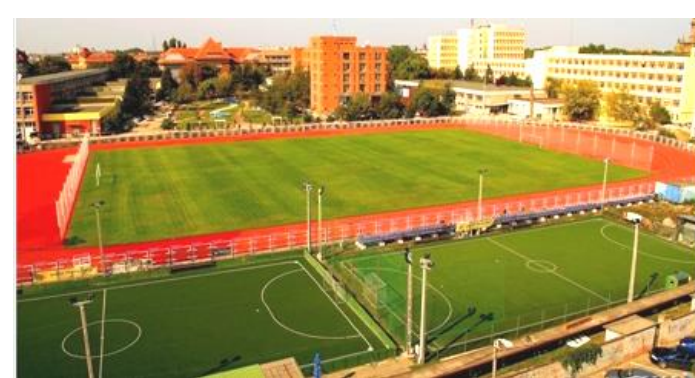

Polytechnic University of Timișoara ${ }^{9}$

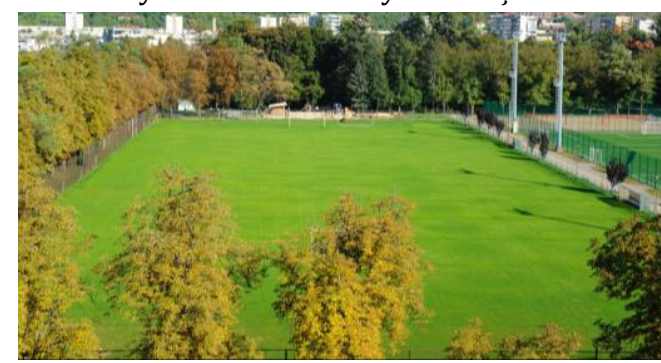

Iuliu Hațieganu Sport Park ${ }^{10}$ of Babeș-Bolyai University of Cluj-Napoca

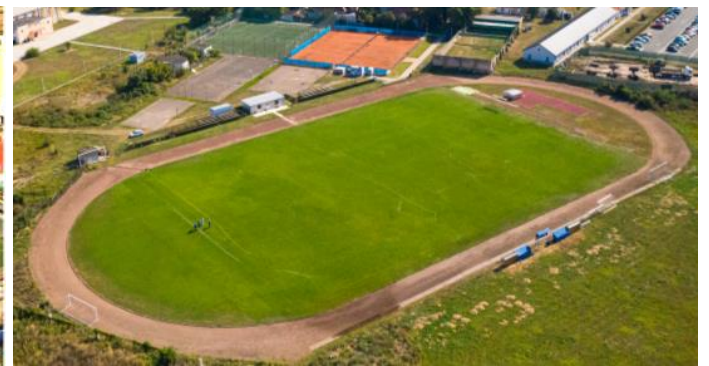

University of Oradea 5

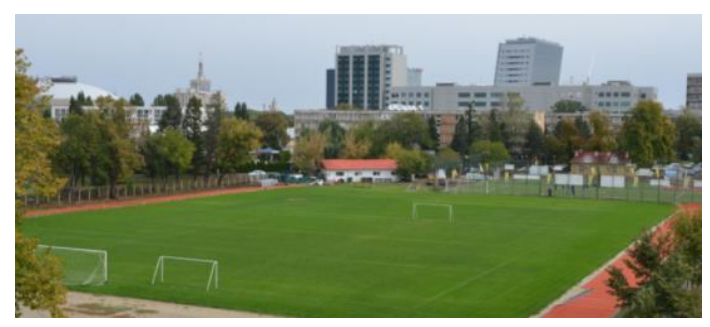

University of Agronomic Sciences and Veterinary Medicine of Bucharest ${ }^{11}$

Figure 3. Football fields în Romanian universities campus

In the case of Romania, the brands Universitatea (University), Politehnica (Polytechnic), Stiința (Science) or Sportul Studențesc (Students Sports), regardless of the level of competition, remained the first option in the collective mind of the city. A good example is the fact that in Cluj Napoca, the CFR 1907 club, with all its European and national performances, cannot overcome the popularity gap of the fellow-club FC Universitatea. Politehnica (Polytechnic) remains the first option for the people of Timișoara (Crețan, 2019), even if traditional clubs like Ripensia have (re)appeared; for Craiova there is no other name, they rather accept that all the teams from Craiova be called Universitatea (the University) etc., and in Iași, after many attempts to rebrand, the traditional name Politehnica (Polytechnic) has returned.

\section{Pro-social arguments}

Along with increasing the attractiveness of the university environment by implementing and supporting a dual system, there are numerous social and psychological arguments that support the continuation of higher-level personal development (Christensen and Sørensen, 2009; Aquilina and Henry, 2010; Candello et al., 2019; Böheim and Lackner, 2012; Dragoș et al., 2019). Among these we mention:

-Reducing the rate of premature dropout of sports activity among young people, especially of those between 16-18 years;

-The decrease in the lack of a life perspective generated by the football practiced in the youthful period;

-According to the already successful models: Australia ${ }^{12}$ USA, Canada ${ }^{13}$, Great Britain, China, Spain (de Subijana et al., 2015), Poland (Graczyk et al., 2017), South Africa (Tshube and Feltz, 2015 etc.), the encouragement of university sports offers 
"an extra chance" for a young person at a young age in the situation of choosing between a job, continue studies or continue sports life.

-Decreasing "critical" situations in the case of pandemics (such as the current one, COVID-19), when sports activity is interrupted for an indefinite period and most young athletes are left without financial resources. Implicitly there is a negative psychological impact generated by the lack of sports perspective, especially in semi-professional football (L2-L3). In the case of university sports the educational alternative offers the perspective of higher qualification profession and the possibility to continue football at amateur or even professional level (by transfer or activating in parallel to an L1-L3 team).

-The perspective for young people (between junior and senior period) to continue their sport life in parallel with a professional training at high school and university level. Following the British or American model (and not only) high schools (especially LPSs) and universities can offer this extra opportunity to young people.

-Unfortunately, a large part of those who reach the age of juniors A (17-19 years old) do not have a sports perspective, more precisely after many years of training they find that their sports horizon is closing. In these cases, for most of them, the chance to activate and continue sports performance at university clubs comes with multiple advantages such as: sports scholarships and merit scholarships, free accommodation in dormitories, sports equipment, awards, access to multiple sources of information; pedagogical and psychological training etc.

-Sport remains the most effective form or tool for promoting an institution: Universitatea/Politehnica are brands that, even if associated with traditional university centers in Craiova, Cluj, Iași or Timișoara, have become famous through sports (especially team sports) and football in particular.

-A large number of young people in the final high school classes can be stimulated by the perspective of performing at a university club to obtain their baccalaureate diploma and understand its importance in their lives.

-Sports scholarships can be stimulating for future students;

-By professional support given to university clubs, a large number of young people can continue their sports life for a period of 3 to 8 years ( 3 years bachelor +2 years master +3 years doctorate), and by continuing their training in sports they can perform also in their sport branch;

-Universities benefit from specialists in combating school dropout and especially in psychotherapy.

\section{The advantages of having a regular university competition may generate:}

-Institutional visibility for universities at the highest level and implicitly increasing the interest for the establishment of university associations/clubs (British and American model);

-The possibility of accrediting specialization programs within an FRFUniversities partnership with an emphasis on athletes who choose the dual option sport-education and for personal development;

-Attractiveness for sponsors and mass media; 
-Substantially low costs compared to amateur and professional football competitions;

-Flexible competitive calendar;

-European competition calendar through EUSA and European and World university tournaments;

-Possibility of concluding mutually beneficial collaboration agreements or partnerships between university clubs and those in professional leagues, as a basis for selection for groups under 23, 21, 20, and 19.

-High level of personal development for the student athlete;

-Decreasing the dropout rate of sports activity in the age range of 16-19 and especially of that over 19 years;

-Increasing the visibility and social insertion of the university and of the university sports club at local, regional and national level;

-Increasing the importance of the sports partnership through a new competition and attracting the existing University Sports Clubs (USC) in these competitions.

\section{Simulation of functional systemic models for organizing university football}

The simulation of an organizational model involves a careful analysis of all endogenous (specific to higher education institutions) and exogenous factors (referring to the local, regional and national environment of competitions).

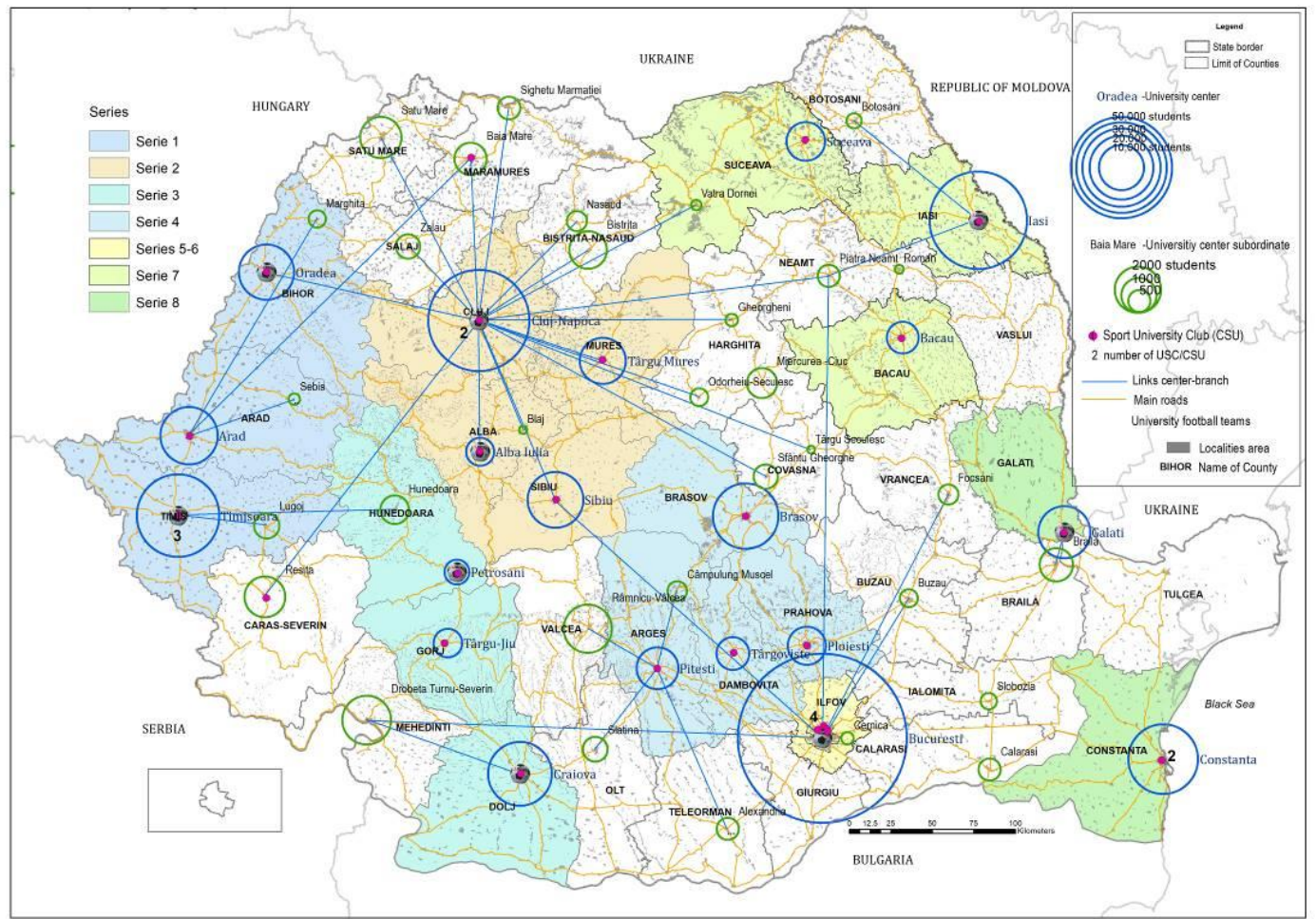

Figure 4. Version 1. Proposal for the organization of the national university football league in Romania on 8 series constituted on the criterion of geographical proximity ${ }^{2}$ 
Based on the geographical criterion, we propose an initial competitive system with 8 series based on the presence (theoretical/hypothetical) of public universities, associations/university sports clubs (other than USC/CSU) and of all 27 USCs. Depending on the affiliation of other private or public universities (including university branches) the number and composition of the series may change. Universities from Bucharest, depending on the number of registered teams, can form two series or a series with two groups.

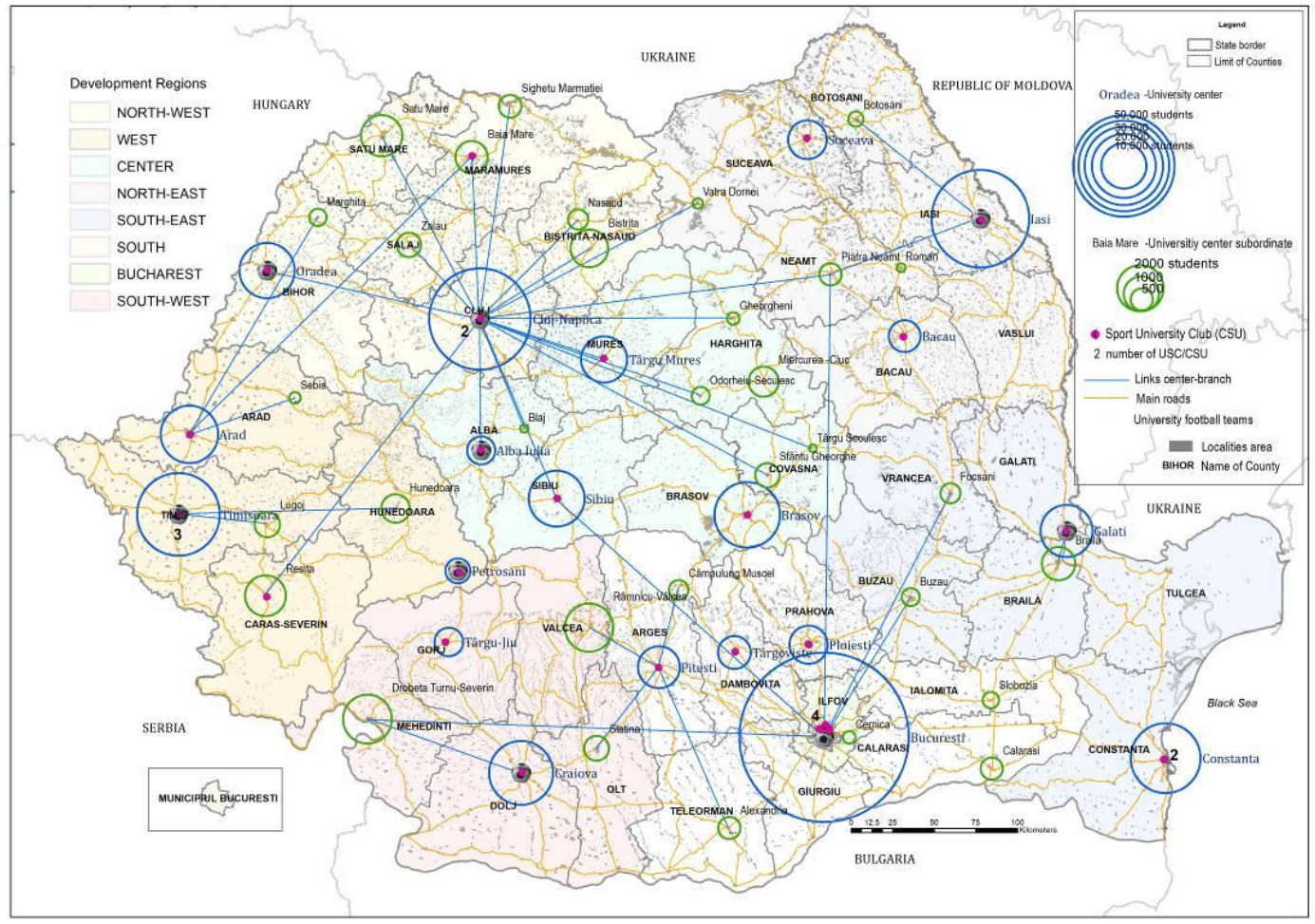

Figure 5. Version 2. Proposal for the organization of the national university football league in Romania on 8 series based on the 8 development regions ${ }^{2}$

Depending on the number of affiliated university sports associations, the territorial structures can be adapted by the efficiency on all levels.

This project was sustained also by the University Amateur Football Association of Romania (UAFAR/AUFAR), with its headquarters in Oradea, and which aims to manage university football competitions in Romania in partnership with FRF and SUSF/FSSU.

Version 1 of geographical proximity, at theoretical level it configures 8-10 series, the main criterion being geographical proximity and economic and temporal efficiency (figure 4).

Version 2 by development regions, which involves 8 groups to which two other groups from Bucharest university center can be added (figure 5). 


\section{Conclusions}

The establishment of a national football university league capitalizing on the network of higher education institutions in Romania (93 institutions) with the human resources, infrastructure and own Romanian expertise, the experience of traditional competition systems such as the British one (bucs), can increase the attractiveness of the Romanian academic system multiplying its curricular and extracurricular offer. Thus: high school graduates who have practiced performance football have an extra chance to continue sport in an organized way $(3+2+3$ years), in parallel with an academic professional training as an alternative for the postsportive period to come; every sports student has an opportunity in sports and at the same time a quality education, a mentality specific to strong characters. Sports in general and university football in particular promote the idea that a valuable education (sports and profession) has major benefits for a young person who chooses a dual career: education and sports. Attracting and integrating young people into academia and ensuring a university education with important current and subsequent benefits in individual development and personal comfort.

The systemic modeling proposes two versions of spatial organization with 820 series/groups that may change depending on the number of participating teams.

Moreover, the capitalization on sports level of the dynamic and static resource of the universities multiplies their professional valences by: Promoting the dual concept of education and sports; Reducing school dropout and increasing the schooling period in the absence of a professional sports career perspective for young people/juniors who practice performance sports; Increasing the degree of insertion on the labor market through the access of young people/juniors to a higher level professional qualification; Through the opportunity offered by a university club, young people/juniors have the chance to continue the sport they loved from childhood; Intellectual stimulation contributes to building the winning mentality in sports and in life, to personal development based on a balance gained from a dual experience generated by passion for sports and academic education.

Finally, this study supports the dual career concept promoted by International University Sports Federation (IUSF/FISU) in relation with national sport university federations and universities "As the bridge where university meets sport, ...in a unique position to shape young lives and impact their futures". ${ }^{14}$

The research article was possible by equal scientific involvement of the authors.

\section{References}

Aquilina, D. \& Henry, I. (2010). Elite athletes and university education in Europe: a review of policy and practice in higher education in the European Union Member States. Int J Sport Pol. 2(1), 25-47. https://doi. org/10.1080/19406941003634024

Augustin, J-P. (2007). Geographie du sport: spatialite contemporaines et mondialisation, Armand Colin, Paris.

Bale, J.R. (2003). Sports Geography, Routledge, London.

Böheim, R., \& Lackner, M. (2012). Returns to education in professional football. Economics Letters, 114(3), 326-328.

Buhas, S.D. (2015). Sports Management. From Institutionalism to Research. GeoSport for Society, 2(1), 26-32. 
Buhaș, S.D., Herman, G.V., Dragoș, P. \& Stance, L. (2017). Football and economy before and after communism in Romania. GeoSport for Society. 6(1), 30-39.

Bulz G.C., \& Ilies, A. (2017). Territorial development indexes for team sports (football). GeoSport for Society, 7(2), 78-83.

Candello, G., Capranica, L., Doupona, M., Varga K. \& Burk, V. (2019). Dual-career trough the elite university student-athletes lenses> The international FISU-EAS survey. PLoS ONE 14(10), e0223278. https://doi.org/10.1371/journal. pone.0223278

Caput-Jogunica, R., C'urković, S. \& Gordana, B. (2012). Comparative analysis: support for studentathletes and the guidelines for the university in southeast Europe. Sport Science, 5, 21-26.

Cartwright, W. \& Ruas, A. (2015). Mapping the world. International Journal of Cartography, 1(1), 1-4. doi: $10.1080 / 23729333.2015 .1062608$.

Chirazi, M. (2019). Comparative evolution of the phenomenon of geography of sports on national and global levels. GeoSport for Society, 10(1), 7-14. DOI: 10.30892/gss.1001-044;

Christensen, M. K., \& Sørensen, J. K. (2009). Sport or school? Dreams and dilemmas for talented young Danish football players. European Physical Education Review, 15(1), 115-133.

Conner, N. (2014). Geography of Sports. Geography, Oxford University Press http://dx.doi.org/10.1093/obo/9780199874002-0067.

Crețan, R. (2019). Who owns the name? fandom, social inequalities and the contested renaming of a football club in Timișoara, Romania. Urban Geography 40(6), 805-825.

de Subijana, CL., Barriopedro, M. \& Conde, E. (2015). Supporting dual career in Spain: Elite athletes' barriers to study. Psychology of Sport and Exercise. 21, 57-64. https://doi.org/10.1016/j.psychsport.2015.04.012

Dehoorne, O., Wendt, J. A., Mikhaylov, A., Berdenov, Z., \& Ilieș, A. (2019). Cartographic representation of a sports (football) competition-UEFA Youth League (2013-2019). Geosport for Society, 11(2), 86-100.

Donnor, K.J. (2005). Towards an interest-convergence in the education of African-American football student athletes in major college sports. Race Ethnicity and Education, 8(1), 45-67. doi: $10.1080 / 1361332052000340999$.

Dragoș, P. (2015). Aspects regarding efficiency at work in certain sport organisations. Geosport for Society, 2(1), 21-26.

Dragoș, P., Herman, G.V., Szabo-Alexi, M., Szabo-Alexi, P., Olău-Varodi \& M., Buhaș, S. (2019). Motivating employees in sports organizations, an important factor in managerial policy. GeoSport for Society, 10(1), 39-47; DOI: 10.30892/gss.1004-047.

Gartner G., \& Huang, H. (2016). Recent research developments in modern cartography in Europe. International Journal of Cartography, 2(1), 1-5. doi: 10.1080/23729333.2016.1187908.

Gayles, G.J., \& Hu, S. (2009). The Influence of Student Engagement and Sport Participation on College Outcomes Among Division I Student Athletes. The Journal of Higher Education, 80(3), 315333. doi: $10.1080 / 00221546.2009 .11779015$.

Georgescu, C. (2015). Mesajul Directorului Federației Sportului Școlar și Universitar (Message from the Director of the Federation of School and University Sports) (web-source: http://fotbaluniversitar.upt.ro/fotbal-universitar/mediul-studentesc-poate-revigora-fotbalul-romanesc/ (accessed on 10.05.2020)

Graczyk, M., Wylleman, P., Nawrocka, A., Atroszko, P., Moska, W., Tomiak, T. \& Krysztofiak, H. (2017). The importance of the type of sport and life experience in the dual career in elite sport based on the analysis of Poland. Baltic Journal of Health and Physical Activity, 9(4), 135-146. https://doi.org/10.29359/BJHPA.09.4.11

Guidotti, F., Cortis, C. \& Capranica, L. (2015). Dual career of European student-athletes: A systematic literature review. Kinesiol Slov. 2015; 21(3): 5-20

Herman, G.V., Buhaș, S.D., Stance, L. \& Pop, A.C. (2016), Considerations regarding the evolution, distribution and dynamics of the romanian football (League I) between 1989 - 2016. GeoSport for Society, 5(2), 69-78.

Herman, G.V., Szabo-Alexi, M., Szabo-Alexi, P., Dragoș, P. \& Marinău, M. (2018). The sport, vector of regionalization / globalization. Case study: International Volleyball Federation (FIVB), GeoSport for Society, 9(2), 88-95

Humphreys, B.R. (2006). The Relationship Between Big-Time College Football and State Appropriations to Higher Education. International Journal of Sport Finance, 1(2), 119-128. 
Ilieș, A., Dehoorne, O., Wendt, A.J., \& Kozma, G. (2014). For Geography and Sport, Sport Geography or Geography of Sport. GeoSport for Society, 1(2), 7-18.

Ilieș, A., Ilieș, D.C., \& Deac, A.L. (2015a). Selective, Subjective or Exclusive Tourist Map. GeoJournal of Tourism and Geosites, 16(2), 217-226.

Ilieș, A., Deac, A.L, Wendt, A.J. \& Bulz, G.C. (2015b). Romanian university sports-cultural landscape defined by the sportive space determined by national competitions (in 2015) in team sports. Geosport for Society, 3(2), 61-87.

Ilieș, A., Stance, L. \& Bulz, G.C. (2016a). Geographical landmarks for delimitation of sport-cultural space defined by amateur football in Crișana and Maramureș (2011-2016), Analele Universităţii din Oradea, seria Geografie, 26( 2), 223-234.

Ilieș, A., Ilieș, M. \& Bulz, G.C. (2016b). History and Tradition on the Maramureș County football map (period 1980-2016), GeoSport for Society. 5(2), 107-132.

Ilies, A., Caciora, T. (2020). Mapping the Scottish university football competitions. A dual performance model: organized sports and professional training. Geosport for Society, 12(1), 72-90. https://doi.org/10.30892/gss.1208-061

Kijewski, T. \& Wendt, A.J. (2019). Polish Football Teams in the Champions League - Does the Budget Decide Everything?, GeoSport for Society, 11(2), 101-112. D0I: 10.30892/gss.1105-053

Kozma, G. (2014). The spatial development of sports facilities within the cities: a Central European case study. GeoSport for Society. 1(1-2), 19-28.

Kozma, G., Bács, Z. \& Zilinyi, Z. (2015). The possibilities and results for the scientific research into the relationship between settlements and sport, GeoSport for Society. 3(2): 41-52.

Lucaciu, G. (2018). Romanian athletics in numbers-a brief analysis, GeoSport for Society. 9(2), 51-62.

Murphy, C. (2019). Designing the imagery on image maps - how far can we take it?. International Journal of Cartography, 5(2-3), 316-331. doi: 10.1080/23729333.2019.1613074.

O'Brien, O., \& Cheshire, J. (2015). Interactive mapping for large, open demographic data sets using familiar geographical features. Journal of Maps, 12(4), 676-683.

Olszewski-Strzyżowski, D.J., (2018), European societies' access to sport-the European Union actions, GeoSport for Society, 9(2), 71-81.

Oros, S., \& Hantiu, I. (2018). Sports career versus educational career. GeoSport for Society, 8(1), 30-39.

Paraschiv, C. (2015). Mesajul managerului de Dezvoltare al Federației Române de Fotbal (The message of the development manager of the Romanian Football Federation). http://fotbaluniversitar.upt.ro/fotbal-universitar/mediul-studentesc-poate-revigora-fotbalulromanesc/(accessed on 10.05.2020)

Reilly, T., \& Gilbourne, D. (2003). Science and football: a review of applied research in the football codes. Journal of Sports Sciences, 21(9), 693-705.

Robinson, A.C., Demšar, U., Moore, A.B., Buckley, A., Jiang, B., Field, K., Kraak, M.J., Camboim, S.P. \& Sluter, C.R. (2017). Geospatial big data and cartography: research challenges and opportunities for making maps that matter. International Journal of Cartography, 3(sup1), 32-60.

Rotar M., \& Ursu, V.E. (2019). English Football in Teams in Inter-War Romania: Football and International Exchanges in the 1930s. The International Journal of the History of Sport, 36(910), 910-931. doi: 10.1080/09523367.2019.1679778.

Stăncioiu, O. (2015). Mediul studențesc poate revigora fotbalul românesc! (The student environment can revive Romanian football!) http://fotbal-universitar.upt.ro/fotbal-universitar/mediulstudentesc-poate-revigora-fotbalul-romanesc/ (accessed on 10.05.2020).

Șerban, V. (2015). Mesajul rectorului Universității Politehnica din Timișoara (The message of the rector of the Polytechnic University of Timișoara). http://fotbal-universitar.upt.ro/fotbaluniversitar/mediul-studentesc-poate-revigora-fotbalul-romanesc/ (accessed on 10.05.2020).

Tight, M. (2002). Do League Tables Contribute to the Development of a Quality Culture? Football and Higher Education Compared. Higher Education Quarterly, 54(1), 22-42. doi:10.1111/14682273.00143.

Tshube, T. \& Feltz, DL. (2015). The relationship between dual-career and post-sport career transition among elite athletes in South Africa, Botswana, Namibia and Zimbabwe. Psychology of Sport and Exercise. 21: 109-114. https://doi.org/10.1016/j.psychsport.2015.05.005 


\section{Web sources:}

${ }^{1}$ http://fotbal-universitar.upt.ro/fotbal-universitar/(accessed on: 10.05.2020)

${ }^{2}$ www.insee.ro (accessed on 16.07.2020)

${ }^{3}$ www.bucs.org.uk, 2020 (accessedon 24.07.2020)

${ }^{4}$ http://fotbal-universitar.upt.ro/istoric/(accessed on 17.06.2020)

${ }^{5}$ https://fcuniversitatea.uoradea.ro/ro/competitii/campionatul-universitar (accessed on 17.06.2020)

${ }^{6}$ https://www.ro (accesed on 20.08.2020)

7 https://www.frf-ajf.ro/ (accessed on 20.06.2020)

${ }^{8}$ https://www.mesagerulhunedorean.ro/din-vara-echipa-de-fotbal-cetate-deva-va-trece-in-subordinea-primariei/ (retrived 17.09.2020)

${ }^{9}$ http://www.upt.ro/Informatii_baza-sportiva-nr1_304_ro.html

${ }^{10}$ https://www.ubbcluj.ro/ro/structura/sport/parcul_sportiv

${ }^{11}$ https://www.usamv.ro/index.php/ro/studenti/sport-si-timp-liber

${ }^{12}$ Australian Government. Australian Institute of Sport, Elite Athlete Friendly University program. 2018. Available from: https://www.ausport.gov.au/ais/personal_excellence/university_network/elite_athlete_ friendly_university_program.

${ }^{13}$ Canadian Sport Institute. Education, Career and Transition: Sportsgrad Program. 2018. Available from: http://csicalgary.ca/life-services/education-career-and-transition.

${ }^{14}$ https://www.fisu.net/education/dual-career 